\title{
Revealed Comparative Advantage of GCC Economies
}

\author{
Munir Hassan ${ }^{1}$, Anwar Al Shriaan ${ }^{1} \&$ Ibrahim Mirza $^{1}$ \\ ${ }^{1}$ Economics Department, Kuwait University, Kuwait \\ Correspondence: Munir Hassan, Economics Department, Kuwait University, Kuwait. E-mail: \\ munir25739@yahoo.com
}

Received: June 6, 2018

Accepted: July 1, 2018

Online Published: September 25, 2018

doi:10.5539/ijef.v10n10p61

URL: https://doi.org/10.5539/ijef.v10n10p61

\begin{abstract}
The main objective of the paper is to analyze the performance of Gulf Cooperation Council (GCC) Economies in terms of their Revealed Comparative Advantage for selected products in recent years. Index of Openness (IO) was calculated for certain selected economies. For most of the study period (2005-2013), the IO was higher for UAE than the other economies. The RCA estimated reveal that UAE had more comparative advantage in Manufactures. The main conclusion form the study is that in spite of decline in growth rates in most of the GCC economies due to the fall in oil prices, liquidity problems, instability and impact of China is declining growth, all the countries have exhibited stability in recent years and are on the path of progress with economic, political, and structural reforms. Attempts are being made in all the countries to revitalize the economy by diversification, improvements in infrastructure and less dependence on oil exports.
\end{abstract}

Keywords: revealed comparative advantage, index of openness, GCC economies

\section{Introduction}

The main objective of the paper is to analyze the performance of GCC Economies in terms of their Revealed Comparative Advantage selected products in recent years. The paper is discussed in four sections. In the first section the Profile of GCC economies is given. The second section is devoted to a review of Literature related to the particular aspect. In the third section, the methodology is outlined and in the fourth section, the comparative analysis of GCC economies is presented. The fifth section deals with the Index of Openness and RCA results and analysis.

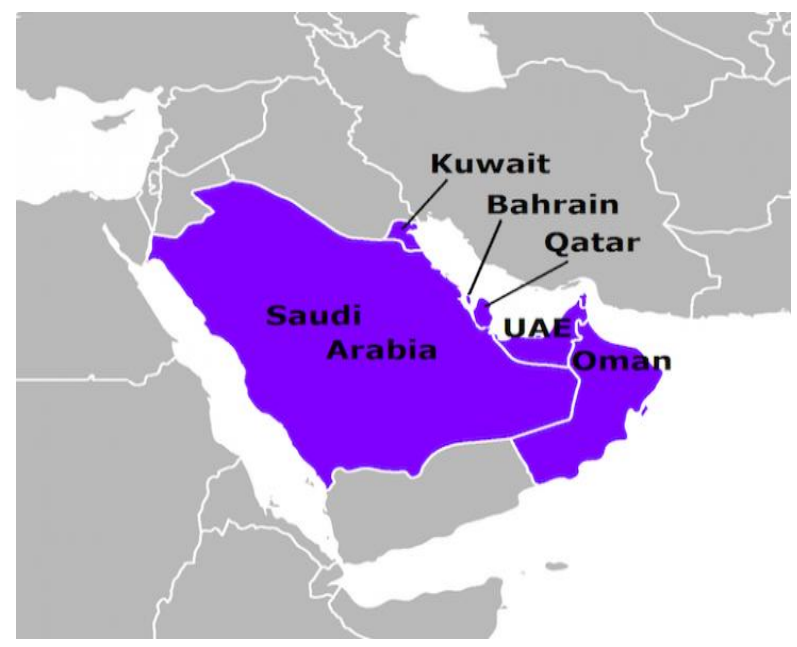

Source: World Atlas.

\section{Profile of GCC Economies}

With the exception of Iraq, GCC countries involve all of the Arab States of the Persian Gulf. The GCC is a political and economic union. 
Member States are Bahrain, Kuwait, Oman, Qatar, Saudi Arabia and the United Arab Emirates. The institution was formally established on 25 May 1981. All current member states are monarchies. Qatar, Kuwait and Bahrain are constitutional monarchies; Saudi Arabia and Oman are absolute monarchies and the United Arab Emirates is federal monarchy and it consists of seven-member states. However, each of the seven-member states is an absolute monarchy with its own emir. (An emir is an aristocratic or noble title of high office used in a variety of places in the Arab countries.

When the sovereign exercises their authorities in accordance with a written or unwritten constitution, it is known as Constitutional monarchy. In absolute monarchy, one ruler has supreme authority and any written laws, legislature or customs do not restrict that authority. Federation of states is a federal monarchy with a single monarch as overall head of the federation. The different states that join the federation retain different monarchs or a non-monarchial system of government.

Saudi Arabia is a leading producer of oil and natural gas. As of 2015, it has $16 \%$ of the world oil reserves. The government revenue decreased considerably due to low global prices. Hence, the government in 2016 introduced a broad set of socio economic reforms referred to as Vision 2030. Subsidies were cut on water, electricity and gasoline, reduced government employee compensation packages and introduced new limited land taxes. The Kingdom of Saudia Arabia has become vulnerable to subdued prices due to the fact that hydrocarbons account for about $80 \%$ of fiscal revenues and more than $40 \%$ of GDP. It is expected that the annual average export prices will recover slowly in 2017 and 2018.

Bahrain attained its independence in 1971. It is stated that the Sunni led governemnt has long struggled to manage relations with its large Shia majority population. The economy has attempted to diversify by developing succesful petroleum processing and refining ,aluminum production and hospitality and retail sectors. It has become a leading regional banking center. It is exposed to financial risks due to (a) low oil and bauxite prices, (b) limited savings and (c) high debt levels. The projections of real GDP growth is 1.9\% decline in 2017 and 2018. It appears to be the most vulnerably GCC economy.

Kuwait got its independence in 1961. In 1990 Kuwait was attacked and ruined by Iraq. Kuwait spent more than $\$ 5$ billion dollars to repair oil infrastructure. Kuwait has witnessed a partial recovery of oil prices and major infrastructure projects continue to support growth. The two key challenges faced by the country include hydrocarbon dependence and parliamentary opposition to deep structural reforms. It is expected that around 2018 , there would be boost in oil production as the government plans to invest US $\$ 115$ billion in the oil sector.

Oman: Since 1970, QABOOS bin Said Al-Said ruled as sultan. The first municipal elections were conducted in 2015. Several economic and political reforms were implemented including increasing unemployment benefits. Oman has large fiscal and current account deficits and it is using external borrowing to finance its deficits. Oman hopes growth to pick up in 2018 due to its economic diversification plan on the fisheries and tourism sectors.

Qatar went through several changes from a poor British protectorate to an independent state with significant oil and natural gas revenues. By 2007, it has attained the highest per capita income in the world. The new ruler TAMIM established advanced healthcare and education systems and expanded the country's infrastructure in anticipation of Doha's hosting of the 2022 World Cup. The low global energy level prices that persisted have shifted Qatar into fiscal and current account deficits. There is scope for Qatar to develop because it has invested US $\$ 200$ billion in infrastructure for upgrade to host the World Cup. The expectation is that with all the externalities the growth is expected to stabilize around $2.5 \%$ in 2019 .It is expected that the fiscal deficit will be less due to savings in current expenditures and reforms and the introduction of VAT in 2018.

United Arab Emirates is a merger of six states. Its per capita GDP is on par with leading West European nations. In order to curb political unrest, the government announced in 2010-2011, a multi-year \$1.6 billion infrastructure investment plan. The low oil prices and fiscal austerity is affecting the UAE's economy for the poorer northern emirates. It also implemented some political reforms. UAE is a member of a US led global coalition to defeat the Islamic state in Iraq. The low oil prices and fiscal austerity is affecting the UAE's economy. The prediction for 2018 is that the oil production is expected to rise due to investments in oil field development. It is predicted that Dubai's hosting of the Expo 2020 would draw large number of visitors that would boost private consumption and service exports.

\section{Review of Literature}

In this section a concise review of literature related to the studies on GCC economies' is given.

In the article on "Oil's fall is a challenge for Gulf economies but also an opportunity", Laura (2016) points out that the GCC economies have depicted remarkable transformation over the past 30 years. GCC advanced into 
one of the world's wealthiest regions due to the discovery and systematic production of oil which provided petro dollars. However, in 2014 the collapse in oil prices has raised concerns for the long-term stability of GCC. As a consequence, it is seen that the International Monetary Fund projects the growth rates to slow downward and run fiscal deficits. GCC economies realized that oil price decline is not a short run phenomenon. Hence, Laura points out that these economies have constructed a new path of growth for their economies with some structural reforms.

Almutari (2016) analyzes the economic diversification of GCC economies. The study uses indirect approaches of measuring dependence of economic activity, budget and external accounts of production and revenues generated by hydrocarbon and non-hydro carbon sectors.

Raghu (2016) shows that there are three main risks for the GCC economies: oil's continuing slide; the draining of liquidity and China's slowdown". The author feels that it is quite possible that with lower revenues for the government along with weakening balance sheets the broader economy could be affected. A second factor is that the ultimate impact could make the cost of capital to rise. The third aspect that would risk the GCC economies is that China's economy is facing a multitude of risks and how things fare will have far-reaching consequences on the GCC.

The Article in Seeking Alpha (2015) points out that GDP growth in UAE has been oil dependent like other GCC countries. However, in terms of GDP growth, UAE outperformed that of many other GCC countries. In UAE, GDP growth is shifting to the services sector (finance and transportation).

Wincher (2010) states that GCC states seemed to be immune as the storms of economic crisis occurred in Europe, Asia, America and the rest of the world in late 2007. It is noted that between 2002-2008, the GCC economy tripled in size. There has been dramatic increase in the number of foreign laborers. During the period the developed economies were severely affected due to sharp increase in oil prices and GCC economies expanded rapidly through growing oil revenues. In 2009 the oil revenues, however, declined and there was considerable diminishing scale of economic activities. Bhatt and Srinivas attempt to analyze the economic development of GCC economies in terms of economic and financial indicators and crude oil production. Their conclusion is that the economic outlook for the GCC economies is positive because since 2002 the global oil prices have moved to even higher thresholds to $\$ 147 /$ barrel in mid-2005.

\section{Data and Methodology}

The main sources of data are the World Fact books and UN Comtrade, Database, 2015.

The variables used for the study are Imports and Exports of the GCC economies. In order to estimate the RCA, the selected products are Manufactures and Machinery and Equipment.

\subsection{Index of Openness (IO)}

The Index of Openness indicator is defined as follows (at current prices, current exchange rates):

$$
\frac{\text { Imports }+ \text { exports (both goods and services) }}{G D P}
$$

In other words IO is defined as the ratio of imports plus exports in the numebrator and GDP in the denominator. These include both goods and services. Goods refer to merchandise imports and exports and the following items are included in services, namely, Transport, travel, communications, construction, IT, financial, other business, personal and government serices, as well as royalties and license fees.

Both imports ane exports are vital to any successful modern ecnomy.By exposing firms and products to global trade and international competition,economies are encouraged to focus on areas of comparative advantage. The IO will be influenced not only by the trade policies adopted by GCC economies and the result of multilateral trade negotiations but alos by the macro state of the world economy.

\subsection{Revealed Comparative Advantage (RCA)}

The Revealed Comparative Advantage (RCA) is a trade analysis tool to measure and assess the competitive advantage of the product which the business people need to export. The RCA indicates whether a country's product is in the process of extending the products in which it has a trade potential or simply competitive advantage.

The Revealed Comparative Advantage (RCA) is defined as a country's sectoral share divided by the world sectoral share. The values of an RCA indicate the country's competitiveness vis-a-vis the world. It also helps to assess a country's export potential.

Revealed Comparative Advantage is used to capture the degree of trade specialization of a country. If the index 
is higher than one, it implies that its exports of those products are more than expected on the basis of its importance in total exports of the world.

$$
R C A i j=(X i j / X i) /(X a j / X a)
$$

RCA index of Revealed Comparative Advantage

$\mathrm{Xij}=$ exports of product $\mathrm{j}$ from country $\mathrm{I}$;

$\mathrm{Xi}=$ total exports from country;

Xaj $=$ total exports of product $\mathrm{j}$ from the world;

$\mathrm{Xa}=$ total exports of the world.

The numerator is the share of good $i$ in the exports of country s, while the denominator is the share of good $i$ in the exports of the world.

\section{Comparative Analysis of GCC Economies}

In this section, a short Analysis of the GCC economies is presented with focus on some of the economic variables. Table 1 presents the data for 2015.

From the Table the following observations may be made:

Table 1. Selected demographic characteristics for selected countries, 2015

\begin{tabular}{lrrr}
\hline Item & Bahrain & Saudi Arabia & UAE \\
\hline Land area (sq. km) & 771 & $2,149,690$ & 83,600 \\
Population, total & $1,371,855$ & $31,557,144$ & $9,154,302$ \\
GDP (current US\$) & $31,125,851,064$ & $654,269,902,889$ & $357,949,199,760$ \\
Foreign direct investment, net inflows (BoP, current US\$) & $-797,074,468$ & $8,141,026,667$ & $8,795,099,000$ \\
Foreign direct investment, net outflows (BoP, current US\$) & $497,340,426$ & $5,389,928,333$ & $16,691,600,000$ \\
Exports of goods and services (current US\$) & $26,327,127,660$ & $218,010,394,722$ & $359,400,953,029$ \\
Imports of goods and services (current US\$) & $22,303,191,489$ & $253,554,611,616$ & $343,716,814,159$ \\
Inflation, GDP deflator (annual \%) & -9.4 & -16.9 & -14.5 \\
Unemployment, total (\% of total labor force) (national estimate) & & 5.6 & \\
\hline
\end{tabular}

Source: Bhatt, GM and Kastoori, Sriaivas (2010) and lobaledge.msu.edu.

- Saudi Arabia is the largest economy and hence has high population and GDP.

- For net inflows the values are positive for UAE, Saudi Arabia, Qatar, and Kuwait. Bahrain, and Oman a have negative values.

- For net outflows of FDI, UAE ranks first and Oman the last.

- A notable feature of all GCC countries is that all with the exception of Saudi Arabia have a trade surplus. Inflation is negative for all countries with Kuwait having a value of -27.2 and Bahrain with a value of -9.4 .

- Unemployment data was unavailable for some of the GCC countries for this particular period.

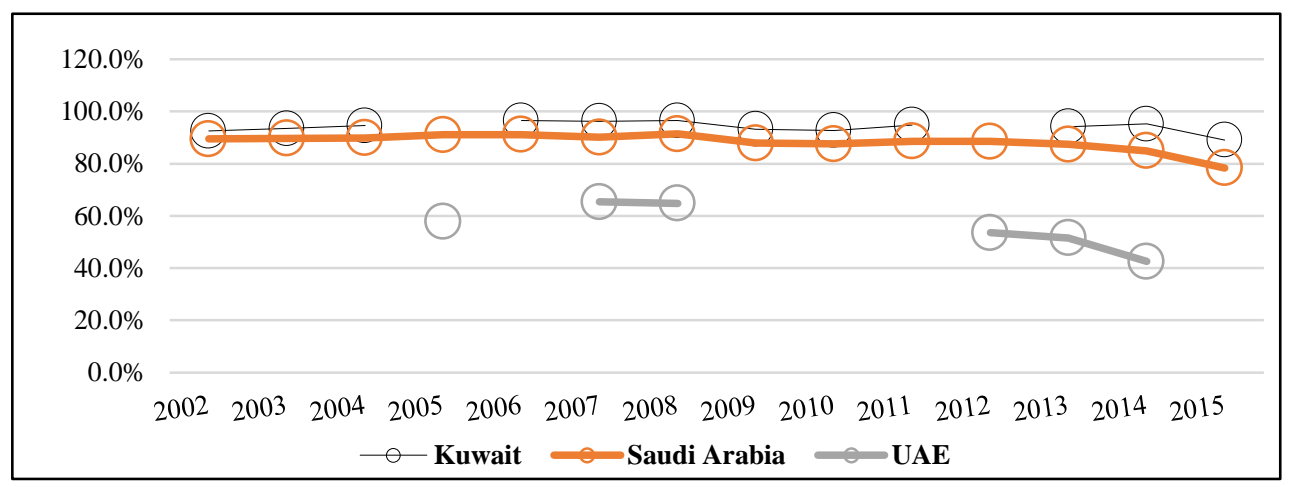

Figure 1. Fuel Exports as a \% of merchandise exports for Kuwait, Saudi Arabia and UAE 
Since most of these economies are dependent on oil for their growth, Figure 1 reveals the relevance of these exports in the total exports. Kuwait has the highest percentage followed by Saudi Arabia. UAE has much less percentages as these economies are also more diversified.

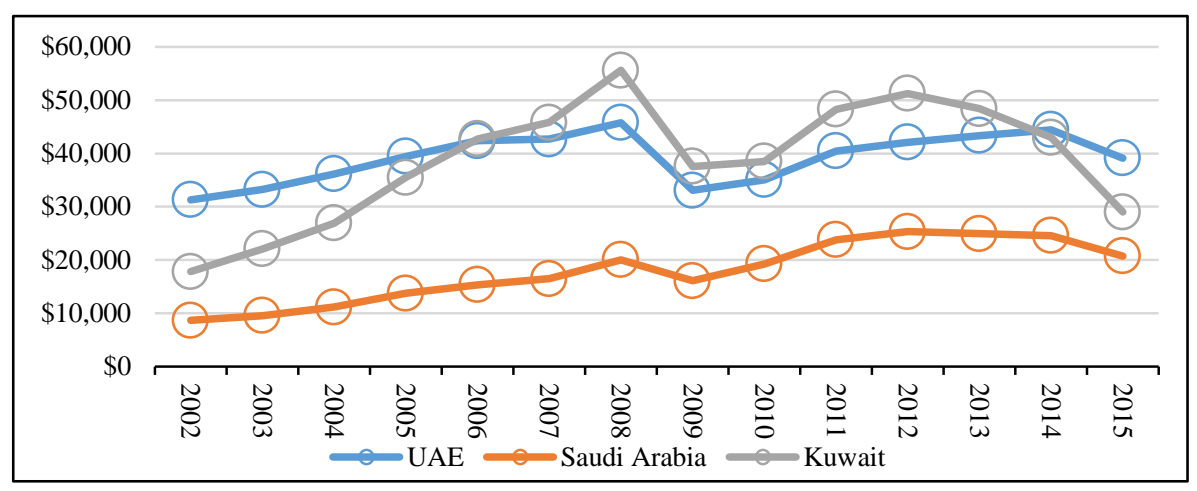

Figure 2. Per capita GDP for the UAE, Saudi Arabia, and Kuwait 2002-2015

From Figure 2, it is observed that there is fluctuation in the per capita GDP for all the three countries. The peak was, however in 2008 for all the countries. Kuwait per capita GDP increased from 2002 to 2008, then started to decline in 2009 and 2010, and then exhibited increasing trends followed by decline in 2015. Kuwait ranks in the middle of Saudi Arabia and UAE for 2015. Saudi Arabia has seen consistently lower than UAE and Kuwait.

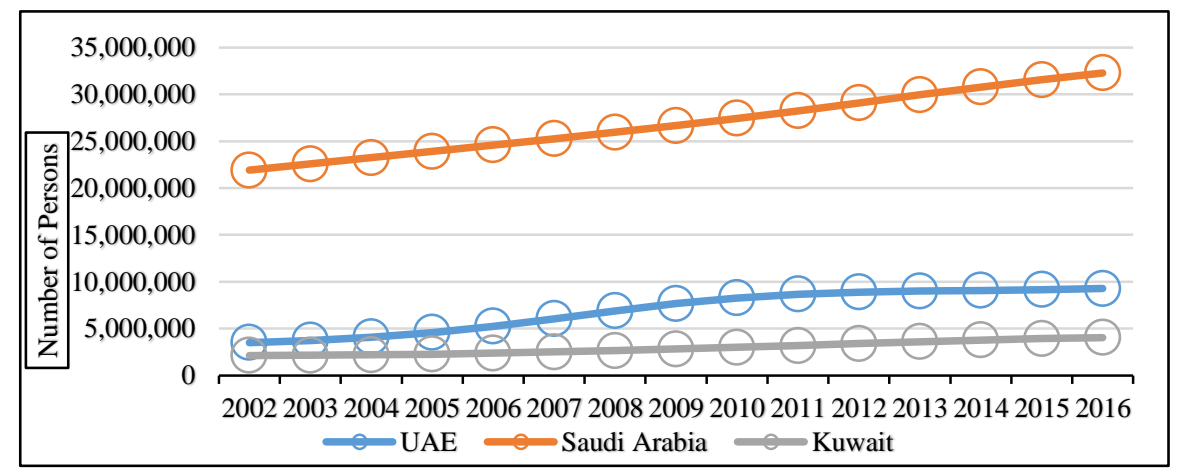

Figure 3. Comparison of the populations of Kuwait, Saudi Arabia and the UAE 2002-2016

Figure 3 shows comparisons of the population for the three GCC countries is given .As expected Saudi Arabia population is much higher than UAE and Kuwait. UAE ranks second and the population has been increasing consistently in all the three countries.

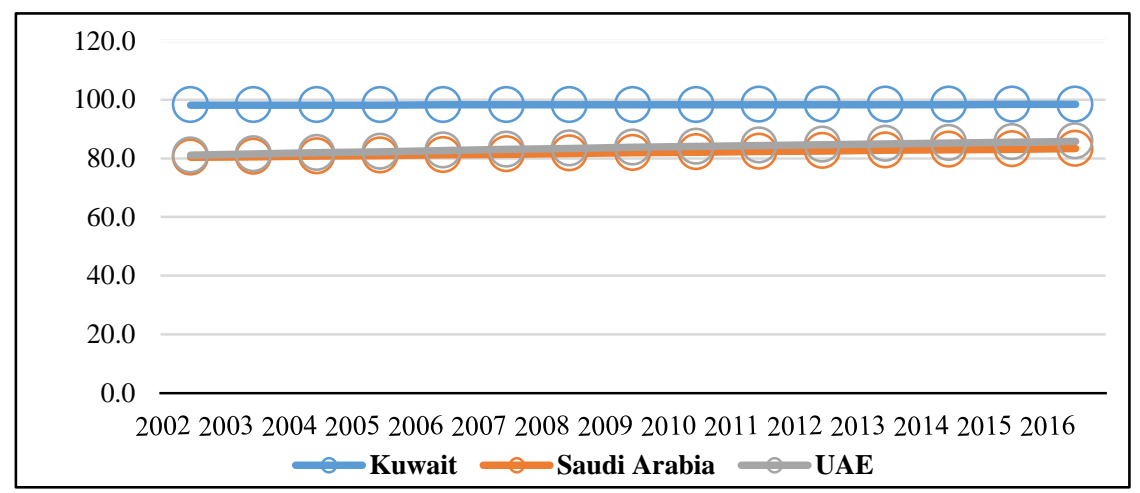

Figure 4. Urban population percentage 2002-2016 
Figure 4 reveals the urban population percentages in the three countries over the period 2002-2016. Kuwait percentages are higher than UAE and Saudi Arabia. The latter two countries had the same percentages. All three countries depict a constant trend for this variable.

\section{Index of Openness and Revealed Comparative Advantage for GCC Economies}

In this section, the emphasis is on three of the Gulf economies, namely, Kuwait. Saudi Arabia and UAE. The following graphs show the comparisons between these countries.

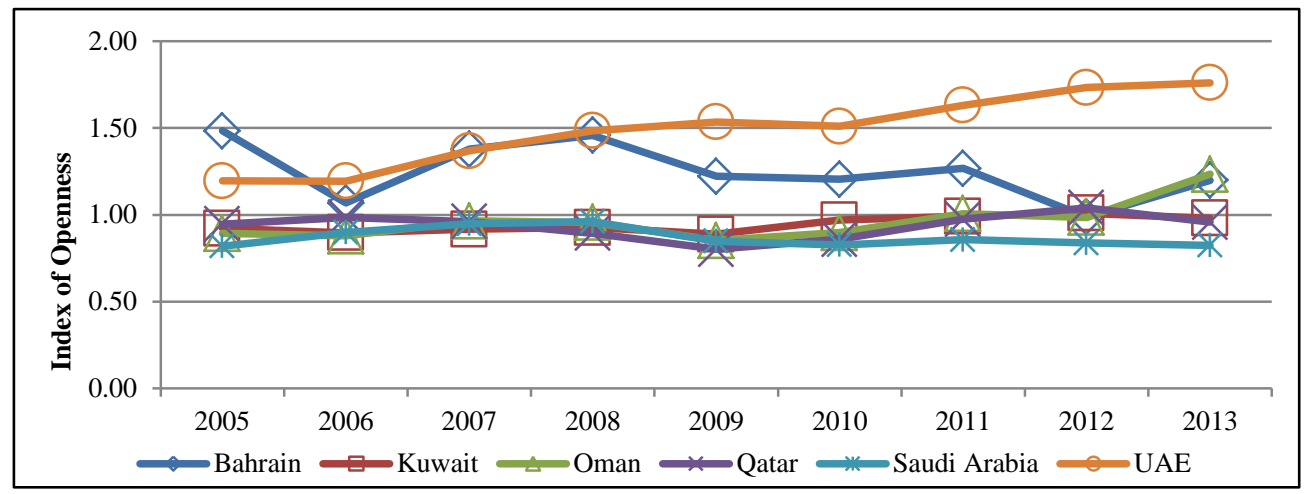

Figure 5. Indexes of openness for all GCC countries

Table 2. Indexes of openness for gulf cooperation council countries

\begin{tabular}{lccccccccccc}
\hline Indicator Name & $\mathbf{2 0 0 3}$ & $\mathbf{2 0 0 4}$ & $\mathbf{2 0 0 5}$ & $\mathbf{2 0 0 6}$ & $\mathbf{2 0 0 7}$ & $\mathbf{2 0 0 8}$ & $\mathbf{2 0 0 9}$ & $\mathbf{2 0 1 0}$ & $\mathbf{2 0 1 1}$ & $\mathbf{2 0 1 2}$ & $\mathbf{2 0 1 3}$ \\
\hline Bahrain - IO & 1.2809 & 1.4074 & 1.4831 & 1.0686 & 1.3778 & 1.4588 & 1.2221 & 1.2047 & 1.2681 & 0.9881 & 1.1990 \\
Kuwait - IO & 0.8656 & 0.8930 & 0.9224 & 0.8971 & 0.9173 & 0.9268 & 0.8881 & 0.9703 & 0.9912 & 1.0101 & 0.9811 \\
Oman - IO & 0.8256 & 0.9024 & 0.8934 & 0.8784 & 0.9647 & 0.9566 & 0.8528 & 0.8982 & 1.0075 & 0.9857 & 1.2342 \\
Qatar - IO & 0.9016 & 0.9037 & 0.9475 & 0.9857 & 0.9611 & 0.8943 & 0.8014 & 0.8595 & 0.9746 & 1.0402 & 0.9581 \\
Saudi Arabia - IO & 0.7023 & 0.7508 & 0.8195 & 0.8994 & 0.9486 & 0.9610 & 0.8486 & 0.8277 & 0.8576 & 0.8374 & 0.8242 \\
United Arab Emirates - IO & 1.0230 & 1.1662 & 1.1955 & 1.1947 & 1.3680 & 1.4851 & 1.5346 & 1.5100 & 1.6313 & 1.7329 & 1.7607 \\
\hline
\end{tabular}

The index is estimated for GCC countries and the values are presented in Table 2. From this Table the conclusion is that for the period 2003 to 2013 the least (.70) in 2003 and the maximum (1.7607) is for UAE in 2013. Kuwait IO value has increased from .86 in 2003 to .9811 in 2013 Observing the comparative figures from Table 2 for 2013, it is observed that the least is for Saudi Arabia and the maximum value is for United Arab Emirates. Kuwait has a value that has increased from .8656 in 2003 to .9811 in 2013 . There have been fluctuations over the years and the maximum value of 1.0101 is observed for 2012 .

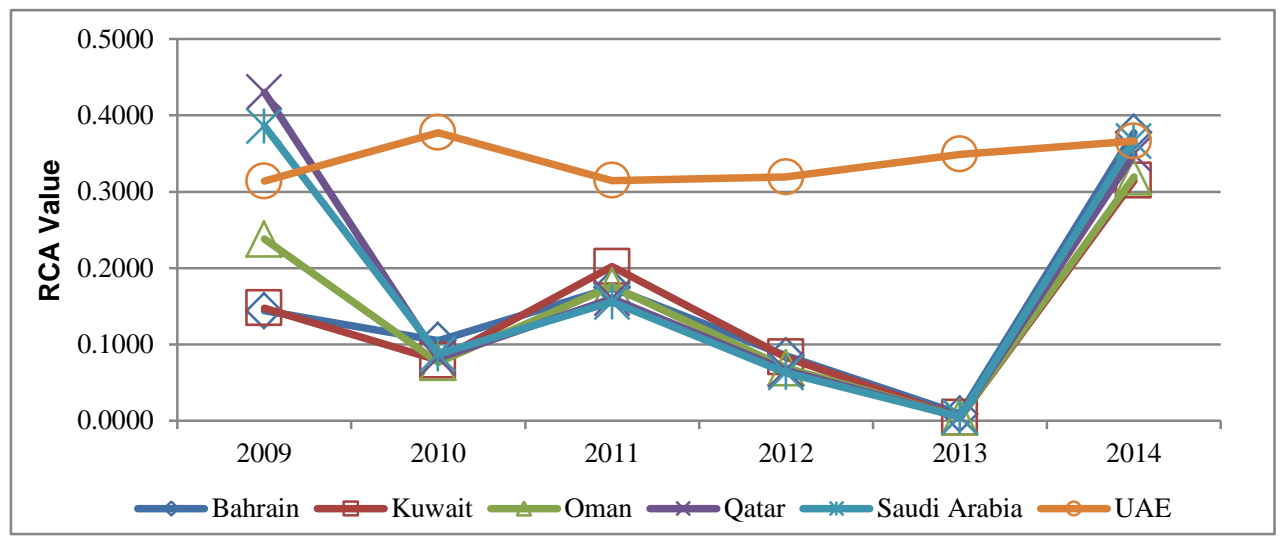

Figure 6. RCA values for manufactures for GCC countries 


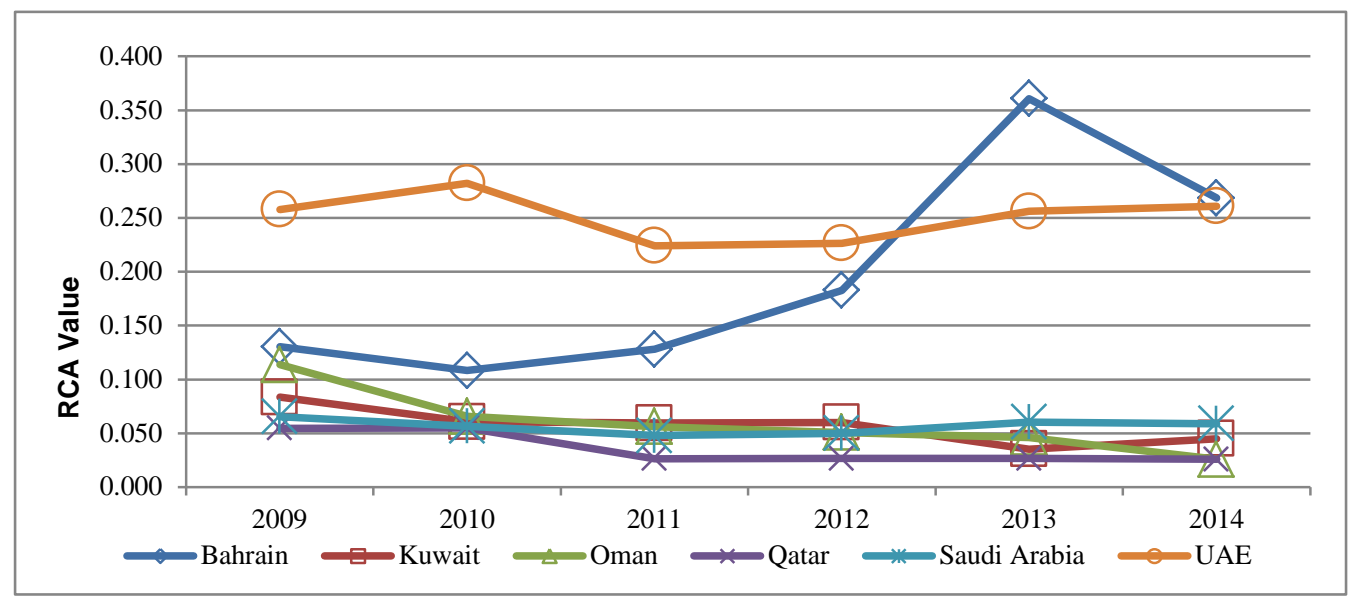

Figure 7. RCA for machinery and transport exports for GCC countries

Table 3. RCA for the manufactures for GCC nations

\begin{tabular}{lcccccc}
\hline Country & 2009 & 2010 & 2011 & 2012 & 2013 & 2014 \\
\hline Manufactures - RCA & & & & & & \\
Bahrain & 0.1829 & 0.1439 & 0.1475 & 0.2378 & 0.4303 & 0.3860 \\
Kuwait & 0.1302 & 0.1049 & 0.0789 & 0.0763 & 0.0819 & 0.0871 \\
Oman & 0.1828 & 0.1742 & 0.2018 & 0.1764 & 0.1602 & 0.1555 \\
Qatar & 0.1053 & 0.0850 & 0.0830 & 0.0692 & 0.0661 & 0.0628 \\
Saudi Arabia & 0.0069 & 0.0084 & 0.0041 & 0.0046 & 0.0048 & 0.0048 \\
UAE & 0.3138 & 0.3775 & 0.3147 & 0.3193 & 0.3492 & 0.3662 \\
\hline
\end{tabular}

Note. These calculations use total merchandise export trade rather than total goods and services exports.

Source: UN Comtrade, Database, 2015; calculations by NDED.

Table 4. RCAs for the machinery and transportation equipment sectors for GCC nations

\begin{tabular}{|c|c|c|c|c|c|c|}
\hline Country & 2009 & 2010 & 2011 & 2012 & 2013 & 2014 \\
\hline \multicolumn{7}{|c|}{ Machinery \& Transport - RCA } \\
\hline Bahrain & 0.1303 & 0.1082 & 0.1280 & 0.1827 & 0.3608 & 0.2685 \\
\hline Kuwait & 0.0834 & 0.0607 & 0.0595 & 0.0600 & 0.0352 & 0.0450 \\
\hline Oman & 0.1137 & 0.0656 & 0.0561 & 0.0507 & 0.0460 & 0.0258 \\
\hline Qatar & 0.0547 & 0.0550 & 0.0265 & 0.0266 & 0.0265 & 0.0258 \\
\hline Saudi Arabia & 0.0655 & 0.0566 & 0.0479 & 0.0500 & 0.0604 & 0.0589 \\
\hline UAE & 0.2579 & 0.2822 & 0.2242 & 0.2265 & 0.2560 & 0.2610 \\
\hline
\end{tabular}

Note. These calculations use total merchandise export trade rather than total goods and services exports.

Source: UN Comtrade, Database, 2015; calculations by NDED.

The other measure that is presented in this section is Revealed Comparative Advantage (RCA). If RCA is less than 1 it implies that the country has a revealed comparative disadvantage in the product and a value greater than one signifies that the country has exported that commodity more intensively than the rest of the world in that year and it is taken as a proxy measure of a country's competitiveness. The RCA was calculated for the years for which data was available and the results are presented in Table 4. It is interesting to note that both manufactures, and High-tech products yielded low values whereas Services revealed high values. These high values for Services could be due to sudden innovations in this area. RCA values were calculated for Manufactures, Machinery and Transport Exports for GCC countries from 2009 to 2014. The results are presented in Figures 6 and 7 and in Tables 3 and 4.

\section{Conclusion}

The main conclusion from the study is that in spite of decline in growth rates in most of the GCC economies due to the fall in oil prices, liquidity problems, instability and impact of China's declining growth, all the countries have exhibited stability in recent years and are on the path of progress with economic, political, and structural reforms. Attempts are being made in all the countries to revitalize the economy by diversification, improvements 
in infrastructure and less dependence on oil exports.

The index is estimated for GCC countries and the values are presented in Table 2. From this Table the conclusion is that for the period 2003 to 2013 the least (.70) in 2003 and the maximum (1.7607) is for UAE in 2013.Kuwait IO value has increased from .86 in 2003 to .9811 in 2013Observing the comparative figures from Table 2 for 2013, it is observed that the least is for Saudi Arabia and the maximum value is for United Arab Emirates. Kuwait has a value that has increased from .8656 in 2003 to .9811 in 2013 . There have been fluctuations over the years and the maximum value of 1.0101 is observed for 2012 .

The RCA was calculated for the years for which data was available and the results are presented in Table 4.It is interesting to note that both manufactures, and High-tech products yielded low values whereas Services revealed high values. These high values for Services could be due to sudden innovations in this area. RCA values were calculated for Manufactures, Machinery and Transport Exports for GCC countries from 2009 to 2014. The results are presented in Tables 6 and 7 and in Tables 5 and 6.

\section{References}

Almutairi, H. (2016). Economic Diversification in GCC Economies: A Heaven for Investors. International Journal of Economics and Finance, 8(4), 84-92. https://doi.org/10.5539/ijef.v8n4p84

Anonymous. (2015). An Analysis of United Arab Emirates GDP Growth In Conjunction With GCC Countries. Retrieved from https://seekingalpha.com/article/3030216-an-analysis-of-united-arab-emirates-gdp-growth-in-conjunction-w ith-gcc-

Anonymous. (2016). Bypassed by Dubai, Kuwait fails to keep up with its neighbours (December 1, 2016). Middle East and Africa-Kuwait City.

Balassa, B. (1965). Trade Liberalization and 'Revealed' Comparative Advantage. Manchester School, 33, 99-123. https://doi.org/10.1111/j.1467-9957.1965.tb00050.x

Balassa, B. (1967). Revealed Comparative Advantage Revisited: Analysis of Relative Export Shares of the $\begin{array}{lllll}\text { Industrial Countries, 1953-1971. Manchester } & \text { School, 45, }\end{array}$ https://doi.org/10.1111/j.1467-9957.1977.tb00701.x

Balassa, B., \& Marcus, N. (1989). Revealed Comparative Advantage in Japan and the United States. Journal of International Economic Integration, 2(2). https://doi.org/10.11130/jei.1989.4.2.8

El-Katiri, L. (2016). Oil's Fall Is a Challenge for gulf Economies, but Also an Opportunity. Harvard Business Review.

IEEE. (n. d.). Xplore Digital Library: Economic developments of GCC countries: An overview. Retrieved from http://www.ieeexplore.ieee.org/document/5609255/

Raghu, M. R. (2010). GCC economies face triple threat in 2016. UAE edition.

Winckler, O. (2010). Can the GCC Weather the Economic Meltdown? Middle East Quarterly, 17(3), 51-61.

World Fact Book. (2016). Central Intelligence Agency (CIA). Retrieved from https://www.cia.gov/library/publications/resources/theworld-factbook/

\section{Websites}

https://hbr.org/.../oils-fall-is-a-challenge-for-gulf-economies-but-also-an-opportunity (Mar 7, 2016)

https://www.imf.org/external/np/pp/eng/2016/102616b.pdf

https://en.wikipedia.org/wiki/Gulf_Cooperation_Council

https://www.cia.gov/library/publications/the-world-factbook/geos/ae.html

http://databank.worldbank.org/data/home.aspx

\section{Copyrights}

Copyright for this article is retained by the author(s), with first publication rights granted to the journal.

This is an open-access article distributed under the terms and conditions of the Creative Commons Attribution license (http://creativecommons.org/licenses/by/4.0/). 